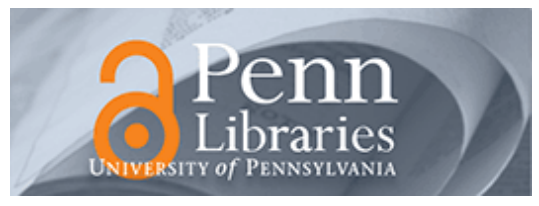

University of Pennsylvania

ScholarlyCommons

Management Papers

Wharton Faculty Research

$1-2004$

\title{
External Churning and Internal Flexibility: Evidence on the Functional Flexibility and Core-Periphery Hypotheses
}

Peter Cappelli

University of Pennsylvania

David Neumark

Follow this and additional works at: https://repository.upenn.edu/mgmt_papers

Part of the Business Administration, Management, and Operations Commons, and the Human

Resources Management Commons

\section{Recommended Citation}

Cappelli, P., \& Neumark, D. (2004). External Churning and Internal Flexibility: Evidence on the Functional Flexibility and Core-Periphery Hypotheses. Industrial Relations, 43 (1), 148-182. http://dx.doi.org/10.1111/ j.0019-8676.2004.00322.x

This paper is posted at ScholarlyCommons. https://repository.upenn.edu/mgmt_papers/14

For more information, please contact repository@pobox.upenn.edu. 


\title{
External Churning and Internal Flexibility: Evidence on the Functional Flexibility and Core-Periphery Hypotheses
}

\author{
Abstract \\ Functionally flexible systems for organizing work may reduce job instability and insecurity by reducing \\ employers' reliance on job cuts or contingent work to respond to changes in their environments. Related \\ arguments hypothesize that contingent work allows firms to adjust labor while "buffering" their core of \\ permanent workers from job instability. We find evidence that internally flexible work systems are \\ associated with reduced involuntary and voluntary turnover in manufacturing but that contingent work \\ and involuntary turnover of the permanent workforce are positively related regardless of sector, in \\ contrast to the prediction of the core-periphery hypothesis.

\section{Disciplines} \\ Business Administration, Management, and Operations | Human Resources Management
}




\title{
External Churning and Internal Flexibility: Evidence on the Functional Flexibility and Core-Periphery Hypotheses
}

\author{
Peter Cappelli \\ Department of Management \\ The Wharton School \\ University of Pennsylvania \\ Philadelphia, PA 19104 \\ and NBER \\ 215-898-2722 \\ David Neumark \\ Department of Economics \\ Michigan State University \\ East Lansing, MI 48824 \\ and NBER \\ 517-353-7275
}

Acknowledgments: The authors thank William H. Carter for careful research assistance, Arne Reznek and colleagues at the Center for Economic Statistics of the U.S. Bureau of the Census for their help with data issues, and Michael Handel, David Levine, and anonymous referees for helpful suggestions. This research is part of a program of studies using the National Employer Surveys that is conducted by the National Center on Post-Secondary Improvement and funded by a grant from the U.S. Department of Education's Office of Educational Research and Improvement. 


\title{
External Churning and Internal Flexibility: Evidence on the Functional Flexibility and Core-Periphery Hypotheses
}

\begin{abstract}
Functionally flexible systems for organizing work may reduce job instability and insecurity by reducing employers' reliance on job cuts or contingent work to respond to changes in their environments. Related arguments hypothesize that contingent work allows firms to adjust labor while "buffering" their core of permanent workers from job instability. We find evidence that internally flexible work systems are associated with reduced involuntary and voluntary turnover in manufacturing, but that contingent work and involuntary turnover of the permanent workforce are positively related regardless of sector, in contrast to the prediction of the "core-periphery" hypothesis.
\end{abstract}




\section{$\underline{\text { I. Introduction }}$}

The issue of job loss and its causes has been a central concern of social scientists. Psychologists have been particularly interested in voluntary turnover-the individual's decision to quit a job-using the employee as the unit of analysis. Indeed, the term "turnover" typically means voluntary quits in most of the psychology-based studies (see Hom and Griffith 1995 for a review). Economists, in contrast, have arguably been more concerned about involuntary turnover-the employer's decision to terminate the relationship through layoffs in particular-focusing to some extent on labor markets as the unit of analysis (Baily 1977; Feldstein 1976; Medoff 1979), and on the incentives posed by the unemployment insurance system (Topel 1984).

The recent scholarly and business practice literature has paid particular attention to job loss and insecurity, to some extent mirroring developments in the economy as a whole. The corporate restructuring and downsizing announcements in the 1980s and 1990s focused attention on the very basic question of whether job insecurity (the risk of losing a job and the related consequences) and job instability (the average time in a job) had changed. While the earlier evidence was divergent, more recent evidence generally points to declines in job stability and job security for at least some groups of workers (see the papers in Neumark 2000). The apparent rise in the use of temporary help, outsourcing, and contractors through the 1990s (Abraham and Taylor 1996) drew attention to a growing sector of nonstandard or "contingent" jobs that were likely less stable and less secure than more traditional employment (Kalleberg 1997; Houseman and Polivka 2000; Polivka, et al. 2000). The interest in understanding the causes of job loss and contingent work are both motivated by the concern that these developments make labor market prospects worse for individuals.

Tight labor markets at the end of the 1990s brought attention to another aspect of job loss, this time from the perspective of employers who were trying to reduce voluntary turnover. Voluntary quits are empirically the largest component of turnover. But unlike involuntary job loss and contingent work, voluntary quits are largely seen as a problem for employers.

The general concern about job stability and security in labor markets, then, encompasses three 
conceptually distinct processes: (1) the employer's decision to cut employees through layoffs or dismissals, or involuntary turnover; (2) the employer's decision to shift employment toward more contingent arrangements; and (3) the employee's decision to quit, or voluntary turnover. The analyses below consider all three processes. Contingent work is an organizational-level characteristic, and one could argue that turnover rates are as well-certainly the practices designed to influence them are. ${ }^{1}$ We therefore focus on policies and practices that are seen as influencing turnover and contingent work and use the organization as the unit of analysis.

The particular issue we study is the relationship between the degree of external churning of employees, as reflected in involuntary and voluntary turnover and contingent work, and the internal organization of work, most importantly the flexibility of that internal organization. ${ }^{2}$ Specifically, we examine the extent to which the kind of flexibility that can be achieved through internal systems for organizing work is a substitute for the numerical flexibility that results from external churning of employees. A large body of research has focused on alternative or flexible work practices, which share characteristics with "high performance" work systems in emphasizing employee involvement and teamwork as mechanisms for organizing work. Most of the research attention given to these practices, though, has focused on claims concerning the consequences of using them for firms, typically estimating effects on productivity or firm performance (Ichniowski, et al. 1997; Cappelli and Neumark 2001). But other arguments, described in detail below, have explicitly asserted that these work practices also reduce involuntary and voluntary turnover as well as the use of contingent work, substituting internal job flexibility for external job churning. The alternative view, associated with systems models, suggests that firms seeking flexibility will do so across all modalities and that we should expect to see external job churning and internal flexibility used concurrently. ${ }^{3}$

In essence, then, we examine the extent to which internal flexibility is a substitute for or a complement to external job churning, taking up Kalleberg's (2001) call for research on these two forms of flexibility. There is no causal argument implicit in these alternative characterizations. Rather, we are simply examining whether firms tend to use internal flexibility and external churning simultaneously, or 
instead tend to trade off one against the other.

We examine evidence on a set of hypotheses regarding internal or functional flexibility and external churning using the 1997 National Employers Survey (NES), a national probability sample of establishments in the U.S. The NES includes data on (1) the organization of work at each establishment, (2) establishment-level involuntary and voluntary turnover, and (3) use of contingent workers at the establishment. Among characteristics of the organization of work, we focus on those that are likely to reflect flexibility in workforce management, which-according to the hypothesis of substitutability between internal and external flexibility-allow employers to reduce job instability and insecurity.

\section{Theoretical Approaches and Hypotheses}

This section lays out the key hypotheses that we study in this paper regarding the relationships between work practices, turnover, and contingent work, which come out of a number of theories and perspectives. There is a very limited amount of research relating work practices to external employment adjustments, discussed below. The evidence on the relationship between flexible work practices and contingent work is, as far as we know, the first of its kind based on a representative sample of establishments. ${ }^{4}$

Flexible Employment Systems, Involuntary Turnover, and Contingent Work 
Most intimately related to the main focus of this paper are a series of arguments about systems of employment that are thought to reduce turnover, most notably involuntary turnover. The historical evidence regarding employer efforts to reduce turnover (particularly involuntary turnover) beginning in the early 1900s included employer policy decisions to bear the costs of carrying some excess workers, collective bargaining agreements that made layoffs more difficult and costly, and internal labor market arrangements such as internal promotions (see, e.g., Jacoby 1984). The more contemporary arguments began in the U.S. during the 1980s with discussions of Japanese management practices, where the assertion was that the practice of lifetime employment, at least among the leading firms that pursued it, was made possible by a series of other practices that provided increased flexibility of workforce management-such as job rotation-and thus reduced the incentive of firms to lay off workers for cyclical or structural reasons (Ouchi 1981; Aoki 1988). Related arguments about how committed and highly skilled workforces could achieve the flexibility of operations needed to stabilize employment were put forward based on European examples of smaller firms with arrangements based on employees making decisions and taking action themselves without being directed by management (Piore and Sabel 1984). These arguments suggested that firms that were internally flexible could become responsive and competitive in their product markets, and were particularly important in Europe where the general impression was that government employment regulations and union restrictions were impeding the competitiveness of firms by reducing their ability to adapt and respond to changing competitive circumstances.

Atkinson (1984) articulated the choice available to employers to meet the need for flexibility that forms the basis for the hypothesis of substitutability between external job churning and internal job flexibility. In particular, he argued that firms could be "functionally flexible," with work organized so that a stable cohort of skilled, cross-functional employees adapt their work and, in turn, the firm, to changes in product demand. Or firms could be "numerically flexible," adjusting the workforce itself to changes in demand, hiring to bring in new skills as needed and, presumably, implementing layoffs to eliminate redundant or obsolete skills, as well as relying more on "contingent" work. The more 
sophisticated version of this argument assumes a continuum between the two where greater functional flexibility reduces the need for numerical flexibility. Innovations in existing products are examples of changes that could best be accommodated by a flexible workforce of experienced employees. If, on the other hand, customers demanded new products that were completely different from the previous ones, it is not so obvious that the current workforce would have the skills and abilities to produce them, and therefore not clear that the changes could be accommodated without churning the workforce.

The distinction between functional and numerical flexibility has been used not just conceptually but in case studies of employment systems in manufacturing around the world. These include, for example, Finland (Penn, et al. 1992), Canada (Grenier, et al. 1997; Pinfield and Atkinson 1988), South Africa (Horwitz 1995), Singapore (Sharna and Luh 1994), Germany, Japan, and France (Lorenz 1992), and especially Britain, where the empirical debate over the extent of functional versus numerical flexibility was particularly intense (for a survey of the debate, see Hunter, et al. 1993). These case studies and the work cited above provide some indication that firms face tradeoffs in using internal or functional flexibility as opposed to external churning or numerical flexibility.

In the U.S., there has been some empirical research on choices of employment systems along criteria similar to functional and numerical flexibility (see Smith 1997 and Kalleberg 2001 for reviews). But for the most part research has focused on examining the extent of numerically flexible arrangements in the economy as a whole, particularly the use of non-standard work (e.g., Kalleberg 1997). Aside from case studies, the question of whether functionally flexible practices actually reduce involuntary turnover and contingent work has not been addressed.

Which practices are central to a functionally flexible system of work organization is not entirely clear from the prior research, but it would seem that the central elements are team-based systems where employees are allowed to initiate decisions, and ancillary practices that support such arrangements. In practice, the characteristics of functionally flexible firms seem very much like those of high performance work systems, especially the emphasis on teamwork and employee involvement. Indeed, some researchers use the term "flexible workplace practices" as a synonym for high performance work 
practices (Gittleman, et al. 1998). Early conceptualizations of high involvement work systems (Lawler 1982) explicitly argued that involvement and flexibility went together as did the descriptions of Japanese practices cited above. The high performance approach is certainly based on high involvement and Japanese work systems; some would argue that they are essentially indistinguishable. ${ }^{5}$

Shifting the focus from involuntary turnover to contingent work, functional flexibility is conceptually related to the use of contingent work in a straightforward manner. Recent surveys of employers find them reporting that their interest in contingent work is based on an interest in achieving greater flexibility in the use of labor to accommodate business demands (e.g., Houseman and Polivka 2001). If that flexibility can be achieved through work organization, then the demand for and use of contingent work should be less.

Based on the preceding arguments, we therefore explicitly consider the hypothesis:

H1: Employers with more functionally flexible work systems, other things equal, should have lower rates of involuntary turnover (through reduced layoffs), and be less likely to use contingent work. ${ }^{6}$

An alternative perspective is that functional flexibility and numerical flexibility may be more complementary than substitutable. Employers facing the need for a great deal of operating flexibility may find that it is easiest to secure it by using both internally flexible systems and external job churning. Simple arguments about diminishing returns suggest that it may be more effective to put one's efforts into multiple mechanisms to achieve a given result than into only one. Models from systems approaches (e.g., Dunlop 1958) make similar predictions and have been illustrated in employment contexts with examples like Katz's (1985) description of how various aspects of the employment system in the auto industry, including both functional and numerical flexibility, adjusted to accommodate the need for change in that industry.

There is also empirical evidence to suggest that functional and numerical flexibility may go together. For example, Rodgers (2000) examines the hypothesis (discussed earlier) that employment 
security is required for high performance work systems, and finds relatively weak evidence for that position in prior studies. The studies that examine relationships between layoffs and high performance work systems find little evidence that they are substitutes. In a cross-sectional study, Drago (1996) finds essentially no relationship between the two. In longitudinal studies, Cappelli (2000) finds some evidence that both overall declines in employment and downsizing (narrowly-defined) were related to at least some practices associated with these work systems, and Osterman (2000) finds a positive relationship between the introduction of high performance work systems and the incidence of layoffs. The above considerations suggest that the predictions of hypothesis H1 could be reversed, leading to:

H1': Internally flexible work systems are associated with higher levels of involuntary turnover, and greater likelihood of using contingent work.

The arguments about functional flexibility discussed in this sub-section (and continued below) are arguments about association. They focus on how functional flexibility and numerical flexibility covary, and not necessarily on the direction of causation. Particularly with respect to involuntary turnover, there are alternative causal stories underlying the predicted associations. For example, the seminal research on teamwork and employee involvement asserts that job security (and therefore a low rate of involuntary turnover) is a precondition for employee involvement (see, e.g., Lawler 1982), while other research suggests that layoffs disrupt employee involvement arrangements (e.g., Buch 1992b). On the other hand, layoffs and the threat of further cuts can facilitate changes in the workplace such as the introduction of employee involvement (see, e.g., Katz 1982). ${ }^{7}$ We therefore need to be cautious in drawing conclusions about the mechanisms that underlie the relationships we find.

\section{Voluntary Turnover and Work Practices}

Although the central hypotheses considered in this paper focus on involuntary turnover and contingent work-i.e., employment insecurity-we also focus some attention on voluntary turnover to better understand the overall relationship between work practices and the stability of the employment 
relationship. ${ }^{8}$ Voluntary turnover is clearly influenced by employer policies and can be explicitly managed (e.g., with buyouts on the one hand and retention policies on the other). Because internally flexible work systems are likely to entail greater investment in workers, they are also likely to lead employers to do more to retain their existing workforce, hence reducing voluntary turnover. In addition, while the psychological literature on voluntary turnover begins with an individual's affective response to a job (Mobley 1982; Hom and Griffith 1995), and arguably the strongest theoretical statements about voluntary turnover are those related to individual commitment (Mowday, et al. 1982), there are related arguments positing a relationship between work practices and commitment, especially practices associated with employee involvement (see Cotton 1993). Finally, some empirical research has examined the relationship between practices that generate employee involvement-particularly the practices associated with high performance work systems-and voluntary turnover directly, finding a negative and significant relationship (Wilson, et al. 1990; Buch 1992a; Arthur 1994; Huselid 1995). This theoretical and empirical work supports the hypothesis:

H2: Employers with teamwork and related practices, other things equal, should experience lower voluntary turnover.

\section{The "Core-Periphery” Hypothesis}

Finally, we examine a related argument regarding the role that contingent work, specifically, plays in explaining job instability and insecurity, focusing on the interrelationship between different forms of external churning of employment, rather than on the relationship between internal and external flexibility. The basic argument, which comes from organizational theory (Thompson 1967), is that organizations have "core" resources that are important to protect and insulate from outside forces such as the market. Some part of the workforce whose skills and abilities are crucial to the organization and are difficult to replace might fit the definition of a core resource. This argument is related to the basic internal labor market view that some jobs are essentially protected from the outside market by internally- 
oriented employment policies (Doeringer and Piore 1971). The second part of the argument is that firms require some degree of flexibility in their workforce-for example, reducing the total amount of labor needed in a recession-which might not be achievable internally with the functional flexibility model. Because firms do not want to get this flexibility at the expense of their core employees, they concentrate the adjustments on a "periphery" of the workforce consisting of workers who are less crucial to the organization, whose peripheral status is institutionalized via employment on a "contingent" basis, especially temporary help and contract work.

In this "core-periphery" model, job instability and insecurity are explicitly redistributed away from a core of permanent employees toward more casual workers on the periphery. The example of Hewlett Packard, where outsourcing was manipulated to maintain stable employment, and product market strategies were chosen to reduce employment swings (e.g., avoiding contract work), has long been a teaching case illustrating how business strategy can help ensure job stability (Beer and Von Werssowetz 1981). Detailed arguments about how firms can buffer employees from job insecurity by redistributing the risk of job loss have also been common (Dyer, et al. 1985).

The concept of a core-periphery organization was made popular by the business practice writings of Charles Handy (1991), and most of the contemporary debate about it has been in Europe (Hakim 1990) and especially Britain, where the contingent workforce is of significant size and has clearly been growing (Hunter, et al. 1993). Most of the research on the core-periphery approach has simply asked employers whether they make use of it. ${ }^{9}$ But in a survey in the U.S. asking employers about their reasons for using temporary help, outsourcing, and subcontracting, one of the least frequently-cited explanations was "providing a buffer for regular staff against downturns in demand," a version of the core-periphery hypothesis (Abraham 1990). And there have been few efforts to examine whether this model actually works, aside from case studies like those cited above. The core-periphery model leads to the hypothesis:

H3: Greater use of contingent work, other things equal, is associated with lower levels of involuntary turnover. 
There is an obvious alternative hypothesis to the core-periphery model that follows the same arguments as those noted above regarding the functional flexibility model, which is that greater use of a contingent workforce may be more complementary than substitutable with numerical flexibility among the permanent workforce. As it may be more efficient to use multiple methods to achieve a given goal, employers who need flexibility may pursue it by using numerical flexibility/layoffs and greater use of contingent work, leading to:

H3': Employers making greater use of involuntary turnover will also use more contingent work.

\section{Data, Variables, and Tests}

\section{Data}

Our data come from an establishment-level survey of employment practices conducted by the U.S. Bureau of the Census for the National Center on the Educational Quality of the Workforce, the second wave of the National Employers Survey (NES II), administered by the Bureau of the Census as a telephone survey in August of 1997 (see Cappelli 2001 for a description). ${ }^{10}$ The sampling frame was drawn from the Census Bureau's Standard Statistical Establishment List (SSEL), targeting business establishments throughout the United States, excluding those with fewer than 20 employees, as well as public-sector employers, non-profit institutions, and corporate headquarters, and sampling larger establishments with much greater certainty. ${ }^{11}$ Because of this, it is important to use the sample weights to obtain estimates representative of the population of sampled establishments.

In administering the NES, the target respondent was the plant manager in the manufacturing sector and the local business site manager in the non-manufacturing sector. Other surveys have targeted the human resource manager. But the goal was to measure how work is actually done in the facility, not the policies that might exist in employee handbooks, so the best person to ask about actual operating practices was the person in charge of operations in the establishment, not the manager in charge of 
personnel policies. The questionnaire was designed to allow for multiple respondents so that information could be obtained from establishments that kept financial information, for example, in a separate officetypically at corporate headquarters for multi-establishment enterprises. Computer Assisted Telephone Interviewing (CATI) was used to administer each survey. ${ }^{12}$

\section{Variables}

Regarding turnover, establishments in the NES II were asked to report the percentage of their permanent workforce that left either voluntarily or involuntarily (separate questions) in the past year. The two turnover questions ask "What percent, or how many, of your permanent workforce left voluntarily (e.g., retired or quit)/involuntarily (e.g., were fired or laid off) in the past year?" Most respondents gave a percentage response, and the remaining responses were converted to percentages by the Census Bureau. With respect to contingent workers, establishments in the NES II are asked whether they had any contract, leased, or temporary agency workers who were not employees of the establishment. ${ }^{13,14}$ These questions are asked for 1996, the most recent complete year.

The more difficult issue is to identify variables that capture work organization systems associated with the internal flexibility model. As noted above, the core element in this model appears to be teambased work systems. The main variables in our data that measure these systems are (1) a general variable measuring the percentage of workers involved in regular meetings to discuss work-related problems, ${ }^{15}$ (2) a more specific variable measuring the percentage of non-supervisory workers in self-managed teams, and (3) the percentage of workers involved in job rotation, a practice associated with the reallocation of work. We also include a variable capturing profit sharing. While profit sharing is not a direct measure of internal flexibility, many observers see it (or stock ownership) as most crucial to supporting employee involvement, in that it creates a financial incentive for workers to act in the interest of the organization (e.g., Appelbaum and Batt 1994). ${ }^{16}$ These variables are used to address hypotheses H1 (and H1') and H2.

Because our key hypotheses concern turnover, it is also essential to control for other "standard" turnover determinants. As Osterman (1987) observed, there are many different theoretical frameworks for explaining employee turnover in organizations. Economists and psychologists, for example, 
developed arguments indicating that the quality of the match between jobs and workers would reduce both voluntary turnover and the component of involuntary turnover associated with dismissals (e.g., Hunter and Schmidt 1982; McCall 1990). The translation to workplace practices seems straightforwardemployers who spend more time and effort in selecting employees should have better matches and lower turnover. Thus, it is important to control in some manner for the extent to which employers invest in employee selection, with the expectation that more intensive selection reduces both voluntary and involuntary turnover.

Wages are also likely related to turnover. Research in economics pursued arguments about wage policies-"efficiency" wages-which lead to wage premiums that create incentives to reduce voluntary turnover (Salop 1979). The arguments about wages and voluntary turnover in one form or another have a long history, albeit often under different headings, and were more or less accepted empirically by those who studied turnover earlier (see, e.g., Price 1977), although some recent research has failed to find support for them (see, e.g., Levine 1993; Powell, et. al 1994; Kim 1999).

Another reason to include wage premium controls is because they may help to capture variation in dismissals for cause, because employees who receive wage premiums have an incentive to behave well and keep their jobs. ${ }^{17}$ Because dismissals for cause are not inherently related to the internal flexibilityexternal churning hypothesis, and cannot be separated in the data from other layoffs, the wage premium controls may capture the component of involuntary turnover associated with dismissals for malfeasance or "shirking," allowing us to better identify the relationship between work practices and involuntary turnover from the variation in involuntary turnover that is driven by layoffs. Wage premiums may also signal better matches that, other things equal, are associated with lower levels of involuntary turnover. Other arguments also relate wage premiums to reduced involuntary turnover, such as that wage premiums reflect firm-specific skills that can reduce layoffs or, working in the opposite direction, that wage premiums are a compensating differential for a higher incidence of layoffs. Thus, we also control for a measure of wage premiums, with the expectation (except for the last argument) that these are associated with lower turnover. 
To account for these standard determinants of turnover, we include two variables available in the NES II that are commonly used to measure the extent to which employers search carefully when hiring new employees. These are the number of applicants interviewed for each position and the number of weeks required to fill a position. These questions are asked for the "typical" worker, and may serve as a proxy for overall selection practices for the establishment, although the question regarding weeks required to fill the position could also reflect tightness of labor markets (see below). In addition, we include a measure of the wage premium for the establishment. This is estimated as the residual from a regression of log average salary of permanent workers on controls for the educational, occupational, sex, and minority composition of the workforce, industry and size controls, and the share of hours that are overtime. $^{18,19}$

In addition to these variables, we extract numerous other control variables from the NES II, which previous research has identified as potential factors driving turnover (e.g., Cotton and Tuttle 1986). These include: the percentage of non-managerial and non-supervisory workers covered by collective bargaining; the percentages of permanent employees that are women or minorities; non-wage benefits; the percentages of the permanent workforce in each of five main occupational categories; the number of months required for a typical worker to become fully proficient, as a proxy for firm-specific skill/training; and controls for workforce education, age of equipment and machinery, multi-unit establishments, and establishment size. ${ }^{20}$ We also control for changing skill requirements, measured in the survey as whether skill requirements have risen or declined in the past three years for the typical worker, as changing skill needs may reflect a need for flexibility in terms of either acquiring skilled workers (internally or externally) if skill needs are rising, or shedding them if skill needs are falling.

An important set of factors to control for are various aspects of volatility that may confound the analyses. In some specifications, we control for two-digit industry, which should capture industryspecific employment volatility. We also include a variable measuring the direction of the change in employment over the previous three years, which may be an especially good control for other factors that are affecting involuntary turnover and may help address some of the earlier concern as to whether layoffs 
affect the use of functionally flexible work practices. ${ }^{21}$ Many of our specifications also incorporate a measure of whether the establishment has undergone re-engineering during the past three years, given the evidence that the structural changes associated with re-engineering can drive layoffs (Kaplan and Murdock 1991). At the same time, we add a variable measuring whether the establishment conducted benchmarking studies (efforts to pursue best practices through comparisons), in an effort to control for establishments that might be better run (e.g., ones that pursue innovative policies of employee involvement and quit-rate reduction simultaneously). Finally, the variable measuring weeks to fill vacancies may also serve to control for local labor market tightness (especially given the inclusion the number of applicants screened), which is a factor potentially driving voluntary turnover.

We report results from the key specifications separately for manufacturing and nonmanufacturing because of evidence suggesting that functional flexibility practices such as teamwork operate differently in these two sectors (Hunter 2000). Front-line work in service industries in particular is distinct in important ways from production work, where many of these practices were first defined. Front-line service work is more interactive and involves co-production with customers. It typically makes greater demands on interpersonal skills, but in many cases fewer demands on technical skills than does manufacturing (see, e.g., Harker 1995). Front-line service jobs may not be as differentiated as in manufacturing; rotation across them may not add as much variety. Service jobs may also be less interdependent (Batt 1999) so that teamwork may offer fewer possibilities for synergies.

Not surprisingly, the requirement that establishments provided data on each of the variables needed for our analysis reduces the available sample size. The top panel of Appendix Table A1 shows how the sample size is reduced as various criteria for inclusion in the sample are imposed. Ultimately, the number of establishments available for analysis is reduced from 3,081 to 1,836 observations, so that 60 percent of the original observations remain. The bottom panel shows the distribution of establishments by industry in the full sample and the sample available for the empirical analysis. The distributions are very similar, indicating that exclusion from the sample based on missing data is largely random with respect to industry. The table also reports the proportion of establishments by size category, and union 
status. Here, too, the distributions in the full sample and the analysis sample are very similar.

Tests

Hypotheses $\mathrm{H} 1$ and $\mathrm{H} 2$ (as well as H1') posit a relationship between establishment-level work systems or practices and turnover (or contingent work). We want to estimate the relationship between flexible practices and turnover, controlling for other exogenous establishment-level variables (denoted X) that might explain variation in turnover, but are not central to our hypotheses. This leads to empirical models that we estimate of the form:

(1) Turnover $_{\mathrm{i}}=\alpha+$ Practices $_{\mathrm{i}} \beta+\mathrm{X}_{\mathrm{i}} \gamma+\varepsilon_{\mathrm{i}}$.

When we estimate these equations for turnover rates (involuntary or voluntary), because there is a cluster of observations with reported turnover rates of zero we use Tobit models with a lower tail of zero. This accounts for the impact on the distribution of the observed residuals of the censoring of observations at zero. ${ }^{22}$ When we estimate equations for the use of contingent workers, we use probit models for whether employers reported using any contingent workers.

There are some limitations of our analysis that must be kept in mind in interpreting the estimates. First, there may be establishment-level characteristics that are unmeasured but correlated with both work practices and turnover, biasing the estimates of $\beta$. Of course, the most direct way to address this issue is to control for as many variables as possible that might affect turnover, leaving random determinants and measurement error in the error term. We believe that we are able to extract a long and fairly complete list of such controls using the NES II. Nonetheless, we cannot rule out this possibility.

Second, there are a couple of potentially serious problems with our measure of contingent work. As noted above, our measure of contingent work is an incidence measure. Houseman (2001) summarizes evidence from three surveys indicating that for the majority of establishments using agency temporaries or short-term hires, these workers represented less than one percent of total employment, while for a smaller number they represented a much larger share. Thus, an incidence measure masks considerable heterogeneity. In addition, we have no detail on the type of services being supplied by contingent workers. It is possible that the role played by contingent workers depends on the type of labor they are 
providing, while our hypotheses can only be tested for contingent work overall. For example, Abraham and Taylor (1996) find that some types of services are more likely to supplied by contingent labor in industries with strongly cyclical or seasonal employment, while other types of services are less likely to be provided by contingent labor (in particular, those that can be done by the existing workforce in offpeak periods).

Finally, internal and external flexibility may be jointly determined. One possibility is that rather than internal flexibility determining the extent of external churning, they may both be driven by changes in product markets or technology, or other developments. In our empirical specifications, however, we control for numerous establishment-level characteristics, including Census two-digit industry dummy variables, size, etc., and we are more inclined to discount an important role for variation within industries (and the other categories for which we control) that could generate a spurious relationship. Nonetheless, the ideal experiment is one in which establishments would exogenously vary work practices, and then passively let turnover and contingent work adjust. But this may not characterize how the data are generated. Another way to think about this problem is that we are interested in evidence on whether internal flexibility and external job churning are substitutable or complementary, but we do not have a source of exogenous variation to identify causal effects. (An analogy would be exogenous price variation that is used to answer questions regarding substitute-complement relationships for standard production inputs in the economic analysis of production functions.)

With respect to hypothesis $\mathrm{H} 3$ (and $\mathrm{H} 3$ '), these limitations regarding joint determination of variables are even sharper, as this hypothesis concerns the association between involuntary turnover and the use of contingent work. We estimate regressions of the form:

(2) Involuntary Turnover ${ }_{i}=\alpha^{\prime}+$ Contingent Work $\beta^{\prime}+\mathrm{X}_{\mathrm{i}} \gamma^{\prime}+\varepsilon^{\prime}{ }_{\mathrm{i}}$.

Ideally, of course, we would like instrumental variables for the use of contingent work, but we are skeptical that there are valid instruments that help explain the variation in contingent work yet do not also affect involuntary turnover directly. Clearly in this case we are considering two types of employment policies that may be chosen jointly, so the qualification has to be stated even more forcefully that the 
estimates should not be interpreted causally, but rather simply as informing us about the partial correlation between involuntary turnover and contingent work after controlling for the variables in X. Note that in estimating equation (2) we do not condition on the other employer practices related to functional flexibility. The assertion of the core-periphery hypothesis is not necessarily that establishments with the same practices will explicitly trade off stability and security for "permanent" workers with reliance on contingent work, but rather that establishments may put in place sets of practices related to flexibility that generate this tradeoff, in which case the inclusion of these practices could represent "over-controlling."

$\underline{\text { V. Results }}$

Descriptive Statistics

To begin, we present some basic descriptive statistics on involuntary turnover, use of contingent work, and voluntary turnover. There are few, if any, other sources of representative data on these variables, and the descriptive results are therefore interesting in their own right. Table 1 reports the means for these-overall, and broken out by industry and establishment size. Involuntary turnover rates range from a low of .022 in utilities to a high of .117 in transportation equipment. Involuntary turnover rates are also high in textiles and apparel, printing and publishing, and transportation equipment, and low in machinery and instruments, communications, finance, and health services. Contingent workers are reported to be used by 41.7 percent of establishments, with use particularly common in printing and publishing, chemical and petroleum, other and miscellaneous manufacturing, and communications, and much less common in retail trade. ${ }^{23}$ Finally, voluntary turnover rates are higher on average, and vary more widely across industries, with the voluntary turnover rate ranging from .065 in utilities to .392 in hotels. Among other industries with high voluntary turnover rates are textiles and apparel, communications, retail, and business services, while those with low rates include insurance and real estate, printing and publishing, and chemical and petroleum industries. By size category, with the exception of the smallest establishments turnover rates generally decline with size, while the use of contingent workers goes up with size (which may be because our variable measures incidence, not the 
proportion of labor supplied by contingent workers).

In Table 1 we also report statistics for two simple consistency checks used to assess the reliability of the data. ${ }^{24}$ The first consistency check is with union status, where we verify that these data replicate the well-known finding that union representation is associated with lower quit rates. The second consistency check is with respect to changes in the size of the establishment's workforce over the last three years. We would expect, for example, that establishments that are shrinking would have greater involuntary turnover, and vice versa, which we find.

Table 2 reports descriptive statistics on the use of the internally flexible work practices we study, overall and disaggregated by non-manufacturing and manufacturing. On average across establishments, 58 percent of workers are involved in meetings to discuss work-related problems, 18 percent participate in self-managed teams, and 20 percent in job rotation. Profit sharing, which is interpreted as "supporting" internal flexibility, is used in 39 percent of establishments. These figures are not very different across the two sectors, although meetings are used more in non-manufacturing, and job rotation (and profit sharing) are used more in manufacturing.

We begin our analysis of the relationship between internal flexibility and external churning in Table 3, which presents descriptive statistics relating the three aspects of job instability and insecurity to the work practices associated with functional flexibility. In this table, in each case we use a categorical distinction between the work practices, transforming those reported as a percentage of workers involved into a "yes/no" distinction based on whether this percentage is greater than zero. In the means, nearly every work practice related to functional flexibility (meetings, self-managed teams, job rotation, and profit sharing) is associated with higher involuntary turnover, greater likelihood of using contingent workers, and higher voluntary turnover, and most of these differences are statistically significant (using difference of means tests) at the five-percent level or better. ${ }^{25}$

The table also reports descriptive statistics for the turnover measures broken down by whether the establishment underwent re-engineering or participated in benchmarking, and by skill changes. While these are control variables in the ensuing regression analysis, they are potentially strongly related to needs 
for either recruiting new workers or shedding existing workers, and hence are of some interest. Reengineering and benchmarking are generally positively associated with higher turnover and greater use of contingent workers. In five of the six comparisons reported these are associated with more external churning, with the differences statistically significant at the five-percent level in four of these comparisons. The only exception is the relationship between benchmarking and voluntary turnover, with this turnover measure significantly lower in establishments using benchmarking. The findings with respect to changes in skill requirements are more ambiguous. First, there are relatively few establishments reporting declining skill requirements, but many reporting either no change or increases. Comparing the latter two, increasing skill requirements are significantly associated with lower involuntary turnover (although the small set of establishments indicating declining skill requirements also has lower involuntary turnover). But increasing skill requirements are significantly associated with greater use of contingent work, comparing either establishments with skill increases to those with no change, or those with no change to those with decreases. This suggests that these firms are using contingent work in part to meet skill needs they cannot easily meet via adjustments among their permanent workers.

The overall message from the comparisons of means for the external churning and internal flexibility variables (the top panel of Table 3 ) is more consistent with the view that internal flexibility is complementary to external churning, as the associations are mostly strongly positive between work and management practices associated with functional flexibility, on the one hand, and involuntary turnover, voluntary turnover, and contingent work, on the other. Next, we explore these relationships in a multivariate framework, controlling for (1) the simultaneous use of the various functionally flexible practices, (2) other variables that are hypothesized to determine turnover (especially selection and wages), and (3) establishment and worker characteristics that may be correlated with both turnover and the variables describing work organization, and looking separately at the non-manufacturing and manufacturing sectors-a distinction that turns out to be quite important. 


\section{Involuntary Turnover}

Table 4 reports estimates of models for involuntary turnover. In the first column, we use a specification simply including the four variables capturing functional flexibility: meetings; self-managed

teams; job rotation; and profit sharing. ${ }^{26}$ When we add all of these practices simultaneously, we find that job rotation is significantly positively related to involuntary turnover. This evidence is more consistent with complementarity between internal flexibility and external churning (H1').

We next explore the robustness of these results to the inclusion of the control variables. In column (2) we add the controls for skill changes, re-engineering, and benchmarking, as well as the variables capturing selection practices and wage premiums (the standard hypothesized determinants of turnover). With regard to the estimated coefficients of these control variables, we find that increased skill requirements are associated with decreased involuntary turnover, more consistent with employers attempting to retain skilled workers, rather than replacing workers whose skills are too low. The estimates indicate that re-engineering is associated with greater involuntary turnover. With the inclusion of these controls, the positive and significant relationship between job rotation and involuntary turnover persists. However, when the full set of establishment and worker controls are included in column (3), this one estimated relationship between involuntary turnover and functionally flexible practices weakens and becomes statistically insignificant. Once the full set of controls is included, the estimated coefficients of the wage premium and selection variables are small and statistically insignificant, indicating that these are not important determinants of involuntary turnover.

One concern in studying the effects of multiple work practices is that the practices may tend to be used together, in which case the estimated associations could appear statistically weaker owing to multicollinearity. In fact the correlations among the functional flexibility work practices are not very high. ${ }^{27}$ Moreover, in column (4) we report results from four separate estimations where each uses the same controls as in column (3), but enters one work practice variable at a time (so that each entry in the column is from a separate regression). The point estimates change little, and the standard errors do not decrease. Overall, then, to this point there is no evidence suggesting a link between internal flexibility 
and involuntary turnover, in support of either $\mathrm{H} 1$ or H1'.

Columns (5) and (6) report results for specifications estimated separately for manufacturing and non-manufacturing establishments. The results differ between the two sectors. For non-manufacturing, the estimated relationship between profit sharing and involuntary turnover is positive and statistically significant, but because this relationship arises for profit sharing alone, and not the other more direct measures of internal flexibility (which profit sharing is hypothesized to support), we do not interpret this as evidence of complementarity between internal flexibility and external churning. In contrast, the results for manufacturing establishments point to some significant negative associations between these practices and external churning, in particular with regard to self-managed teams and profit sharing, supporting H1. Thus, there is really no strong evidence one way or the other in the non-manufacturing sector, but there is evidence consistent with substitutability in the manufacturing sector.

\section{Contingent Work}

While the previous table looks at the conventional involuntary turnover rate as a measure of external churning, Table 5 looks at use of contingent work, the growth of which is a relatively recent phenomenon, but one that appears to associated with less stable employment (Houseman and Polivka 2000) and hence is an alternative indicator of external job churning. We report results from probit models, after transforming the coefficient estimates to give the partial derivatives of the probability of using contingent workers with respect to the independent variables. Other than this difference, the set of specifications is identical to that in Table $4 .^{28}$

In column (1), including just the four work practice variables, only profit sharing is significantly associated with the use of contingent work, with a strong positive relationship (boosting the likelihood of contingent work by 18 percentage points). When the first set of controls is added, in column (2), we see that establishments with increasing skill requirements are more likely to use contingent work, and vice versa, a finding that persists in column (3). This is consistent with Houseman's (2001) finding that when asked why they use agency temporaries, 10.3 percent of respondents in her survey indicated that it was because of "special expertise possessed by this type of worker." When these controls are added, the 
positive relationship between profit sharing and contingent work persists, but the evidence also points to a significant negative relationship between self-managed teams and the use of contingent work. This latter relationship becomes statistically insignificant when the full set of controls is added in column (3), which is also the case when the functional flexibility practices are entered singly. Overall, then, the only significant evidence regarding contingent work comes from profit sharing, and since this is interpreted as supported internal flexibility, but not as providing this flexibility in and of itself, this suggests that we should not interpret the results as informative about hypotheses $\mathrm{H} 1$ and $\mathrm{H} 1$ '.

The estimates for non-manufacturing establishments and manufacturing establishments again differ, but not in the same way as they did for involuntary turnover. In particular, for non-manufacturing establishments the positive relationship with profit sharing persists (paralleling the results for involuntary turnover). Again, we do not believe much should be made of these results for non-manufacturing, since the evidence stems solely from profit sharing. In manufacturing, the estimated coefficient for selfmanaged teams is consistent with complementarity between internal flexibility and contingent work, in contrast to the findings for involuntary turnover in manufacturing (and some of the results for voluntary turnover in manufacturing that follow), although the fact that this evidence arises for only one work practice should give one pause in interpreting this evidence too strongly.

\section{Voluntary Turnover}

Table 6 turns to voluntary turnover, presenting estimates of the same specifications as those in Tables 4 and 5, but with the voluntary turnover rate as the dependent variable. In column (1), for the most part the relationships from the bivariate comparisons in Table 3 are unchanged, with meetings, job rotation, and profit sharing positively associated with voluntary turnover. The one exception is for selfmanaged teams, for which the estimated relationship becomes negative (and statistically significant), although this finding does not persist in the ensuing specifications.

In column (2) the results indicate that skill increases and decreases are not significantly associated with voluntary turnover. As hypothesized, voluntary turnover is significantly negatively related to both the intensity of selection procedures and the wage premium paid by the establishment. The estimated 
relationships between voluntary turnover and the functional flexibility work practices are largely unchanged with the inclusion of the controls in column (2). But when the full set of establishment and worker controls are included in column (3), the changes are somewhat sharper. The estimated relationship between self-managed teams and voluntary turnover becomes much weaker and statistically insignificant, as does the estimated relationship between voluntary turnover and profit sharing.

For voluntary turnover, the wage premium effect is strongly negative, while the evidence regarding selection is less clear-cut. The estimated coefficient of the number of candidates interviewed is strongly negative, but that of weeks to fill the opening is positive. Recall, though, our earlier suggestion that the latter variable may also reflect market conditions; a positive coefficient is also consistent with tight labor markets associated with both high turnover (as quits are higher) and more difficulty finding candidates. Thus, candidates interviewed may be a more reliable indicator of selection intensity, and consistent with more intensive selection reducing voluntary turnover. ${ }^{29}$

The next column reports results from using the functional flexibility work practices one at a time. Most of the estimates and standard errors are in fact little different from those in column (3), although the positive estimated relationship with self-managed teams becomes statistically significant. Overall, the findings to this point indicate that the functional flexibility variables are positively related to voluntary turnover (two of the four variables), in contrast to H2. Instead, these results are more consistent with the notion that functional flexibility and external churning vary together in a complementary fashion, at least with respect to voluntary turnover.

As reported in columns (5) and (6), like for involuntary turnover and contingent work, the results differ between non-manufacturing and manufacturing establishments, although here more sharply. The results for non-manufacturing establishments largely mimic those for the full sample (column (3) is most comparable), with a stronger positive relationship between job rotation and voluntary turnover. On the other hand, the nature of the evidence for manufacturing establishments is substantially different. For three of the four functionally flexible practices (self-managed teams, job rotation, and profit sharing) the evidence points to significant negative associations with voluntary turnover, supporting H2. Only for 
meetings is the evidence in the positive direction. ${ }^{30}$ Thus, the overall evidence on voluntary turnover is generally more consistent with complementarity between internal flexibility and external churning in the non-manufacturing sector, but more consistent with substitutability in the manufacturing sector.

\section{The Core-Periphery Hypothesis}

Finally, Table 7 turns briefly to the question of contingent work and the core-periphery hypothesis that utilization of contingent work will be associated with lower involuntary turnover among the permanent workforce, as churning is shifted from core permanent employees to peripheral nonpermanent employees. We begin with the simple bivariate regression of the involuntary turnover rate on use of contingent workers, and do not find the negative relationship predicted by the core-periphery hypothesis $\mathrm{H} 3$, but rather a positive although insignificant relationship. When we add controls in columns (2) and (3) for the standard economic determinants of involuntary turnover, and the establishment and worker controls, this positive association strengthens and becomes statistically significant. We do not include the variables capturing functionally flexible work practices because the core-periphery hypothesis does not concern them; nothing in the core-periphery hypothesis rules out alternative internal work practices supporting both approaches to external flexibility. Finally, in columns (4)-(5) we report the estimates for non-manufacturing and manufacturing establishments. In all cases, the positive association is robust. We do not find support for the core-periphery hypothesis (H3) in any case. Instead, the use of contingent work is positively related to numerical flexibility in the form of involuntary turnover, suggesting that these are complementary practices. 


\section{$\underline{\text { VI. Conclusions and Discussion }}$}

Our analysis uses a national probability sample of establishments to test hypotheses regarding job instability, job insecurity, and contingent work, or more generally churning of workers that is external to the firm or establishment. The focus of our study is on the relationships between external job churning and flexible work systems whose characteristics overlap those of high performance work systems in fundamental ways. These work systems are presumed to give employers flexibility in managing their workforce in terms of reorganizing, reallocating, or retraining their employees to respond to contingencies posed by changing markets, technologies, etc.

One central hypothesis we examine is that external churning and internal flexibility are substitutable; establishments need flexibility in their workforce in order to respond to change and can obtain it by relying more on external adjustments and less on internal flexibility, or vice versa. Alternatively, external job churning may be more complementary with internally flexible systems, perhaps because common influences require flexibility on both fronts, or even because external churning facilitates the implementation of internal flexibility. ${ }^{31}$ Finally, we examine the related "core-periphery" hypothesis that employers choose between relatively high involuntary turnover among core employees or reliance on flexible peripheral, largely contingent workers.

There are important limitations in trying to establish causal effects of flexible work systems on turnover and use of contingent work. Consequently, our findings should be viewed more as establishing the empirical associations between internal flexibility and external churning after accounting for a rich array of establishment and workforce characteristics, as well as other determinants of turnover, and providing some evidence on the consistency of the data with the various hypotheses, than as providing causal estimates. Viewed in this light, the evidence paints a rather clear picture regarding the coreperiphery hypothesis, as we find that contingent work and involuntary turnover of the permanent workforce are positively and significantly related, contradicting the "core-periphery" hypothesis. But because of data limitations in measuring contingent work and difficulties in drawing causal inferences, strong conclusions regarding the core-periphery hypothesis should await further research. 
The question of whether internal flexibility and external churning appear more substitutable or complementary-the main focus of the paper-receives a mixed answer depending on the sector. In manufacturing, the evidence regarding involuntary and voluntary turnover is more consistent with substitution between internal flexibility and external churning, which we interpret as to some extent consistent with existing case studies of this sector. Contingent work is positively associated with internally flexible work practices in manufacturing, but this evidence is weaker. In non-manufacturing, in contrast, internal flexibility and external churning are positively related, but only with respect to voluntary turnover, which is perhaps not as closely tied to job instability and insecurity as are involuntary turnover and contingent work.

The natural question to which these differences lead is why these relationships should differ between non-manufacturing and manufacturing. Some part of the explanation may be that the type of flexibility needed in the two sectors makes different demands on the workforce. For example, in the nonmanufacturing (primarily services) sector, the "product" is often indistinguishable or difficult to separate from the employees, so that variations in product demand lead much more quickly to variations in the amount of labor required. There is, for example, no equivalent of inventory in the service sector and hence it is difficult to keep workers productively occupied with even temporary downturns in business. Thus, while in manufacturing flexible practices may largely accommodate variations in the type of products produced-variations that may require employee creativity and input to solve-in services the flexibility is more likely to address variation in peak demand (such as increased business during holiday periods), which require adjustments in the pace of work and in work schedules or in the amount of labor per se. In addition, some critics of high performance work practices note that they may be used to increase the pace of work and the intensity of effort, outcomes that may drive turnover and may be more likely to occur in the service sector where work is less machine-paced (e.g., Parker and Slaughter 1988). Evidence suggests that these high performance practices may actually produce adverse effects in some service jobs. For example, teamwork and flexible assignments together appear to be associated with worse performance in retail banks (Hunter and Hitt 2001). 
Further, as noted earlier, these work practices may mean very different things in the two sectors. Job rotation or teamwork, for example, has a very precise meaning in the context of manufacturing operations where it is part of an overall approach to production, such as Japanese management and continuous improvement, which often includes protecting permanent employees as an explicit goal. What these practices mean in the context of an insurance office, retail store, or some other component of the service sector where the logic of the above underlying production systems do not apply may differ. The ability to use self-managed teams and job rotation in these contexts may be an indication that the individual jobs are largely undifferentiated, for example, which may make it easier to churn workers. These practices may also be an indication of especially great pressure to achieve flexibility, and, again, product market demand variation in the non-manufacturing sector may place more immediate demands on the flexibility of labor input. At a minimum, these results imply that what we can learn generally about the relationships between functional flexibility and external churning from studies of manufacturing establishments-with which most of the prior studies have been concerned-may be limited. In particular, the manufacturing-based studies may not tell us a great deal about conditions faced by much of the workforce or most employers. For them, the spread of flexible or "high performance" work systems appears to offer little protection from job churning.

\section{$\underline{\text { References }}$}

Abraham, Katharine G. 1990. "Restructuring the Employment Relationship: The Growth of MarketMediated Work Arrangements.” In New Developments in the Labor Market: Toward a New Institutional Paradigm, edited by Katharine Abraham and Robert McKersie, pp. 85-119. Cambridge, MA: MIT Press.

Abraham, Katharine G., and Susan K. Taylor. 1996. 'Firms' Use of Outside Contractors: Theory and Evidence.” Journal of Labor Economics 14 (July):394-424.

Aoki, M. 1988. Information, Incentives, and Bargaining. New York: Cambridge University Press. Appelbaum, Eileen, and Rosemary Batt. 1994. The New American Workplace: Transforming Work Systems in the United States. Ithaca, NY: ILR Press.

Arthur, Jeffrey B. 1994. "Effects of Human Resource Systems on Manufacturing Performance and 
Turnover.” Academy of Management Journal 37 (June):670-687.

Atkinson, James. 1984. "Manpower Strategies for Flexible Firms.” Personnel Management 16

(August):28-31.

Baily, Martin N. 1977. "On the Theory of Layoffs and Unemployment.” Econometrica 45

(July):1043-1064.

Batt, Rosemary. 1999. "Work Organization, Technology, and Performance in Customer Service and

Sales." Industrial and Labor Relations Review 52 (July):539-561.

Beer, Michael, and Richard O. Von Werssowetz. 1981. Human Resources at Hewlett-Packard.

Boston, MA: Harvard Business School.

Blackburn, McKinley, and David Neumark. 1992. "Unobserved Ability, Efficiency Wages, and

Interindustry Wage Differentials.” Quarterly Journal of Economics 107 (November):1421-1436.

Brown, Charles, and James Medoff. 1989. “The Employer Size-Wage Effect.” Journal of Political

Economy 97 (October):1027-1059.

Buch, Kimberly. 1992a. "Quality Circles and Employee Withdrawal Behaviors: A Cross-

Organizational Study.” Journal of Applied Behavioral Science 28(March):62-73.

Buch, Kimberly. 1992b. “How Does Downsizing Affect Employee Involvement?” The Journal of Quality and Participation 15 (March):74-80.

Cappelli, Peter. 2000. "Examining the Incidence of Downsizing and Its Effect on Establishment

Performance.” In On the Job: Is Long-Term Employment a Thing of the Past?, edited by David Neumark, pp.

463-516. New York, NY: Russell Sage Foundation.

Cappelli, Peter. 2001. "The National Employer Survey: Employer Data on Employment Practices."

Industrial Relations 40 (October):635-647.

Cappelli, Peter, Laurie Bassi, Harry Katz, David Knoke, Paul Osterman, and Michael Useem. 1997.

Change at Work. New York, NY: Oxford University Press.

Cappelli, Peter, and Keith Chauvin. 1991. “An Inter-Plant Test of Efficiency Wage Arguments.” 
Quarterly Journal of Economics 106 (August):769-787.

Cappelli, Peter, and David Neumark. 2001. "Do "High Performance” Work Practices Improve

Establishment-Level Outcomes?” Industrial and Labor Relations Review 54 (July):737-775.

Carmichael, Lorne. 1983. "Firm-Specific Human Capital and Promotion Ladders.” Bell Journal of

Economics 14 (Spring):251-258.

Cotton, John L. 1993. Employee Involvement: Methods for Improving Performance and Work

Attitudes. Newbury Park, CA: Sage Publications.

Cotton, John L., and Jeffrey M. Tuttle. 1986. "Employee Turnover: A Meta-Analysis and Review

with Implications for Research.” Academy of Management Review 11 (January):55-70.

Dalton, Daniel R., David M. Krackhardt, and Lyman W. Porter. 1981. "Functional Turnover: An

Empirical Assessment.” Journal of Applied Psychology 66 (December):716-721.

Doeringer, Peter, and Michael J. Piore. 1971. Internal Labor Markets and Manpower Analysis.

Lexington, MA: D. C. Heath.

Drago, Robert. 1996. “Workplace Transformation and the Disposable Workplace: Employee

Involvement in Australia.” Industrial Relations 35 (October):526-543.

Dunlop, John T. 1958. Industrial Relations Systems. New York: Henry Holt and Company.

Dyer, Lee, Fred Foltman, and George Milkovich. 1985. "Contemporary Employment Stabilization

Practices." In Industrial Relations and Human Resource Management, edited by Thomas A. Kochan and

Thomas A. Barocci (eds.), pp. 203-214. Boston, MA: Little, Brown.

Feldstein, Martin. 1976. "Temporary Layoffs in the Theory of Unemployment." Journal of Political

Economy 84 (October):937-958.

Gittleman, Maury, Michael Horrigan, and Mary Joyce. 1998. "Flexible Workplace Practices:

Evidence from a Nationally Representative Survey.” Industrial and Labor Relations Review 52 (October):99115.

Grenier, Jean-Noel, Anthony Giles, and Jacques Belanger. 1997. “Internal Versus External Labour Flexibility: A Two-Plant Comparison in Canadian Manufacturing." Relations Industrielles-Industrial 
Relations 52 (Fall):683-711.

Hakim, Catherine. 1990. “Core and Periphery in Employers' Workforce Strategies: Evidence from the 1987 E.L.U.S. Survey.” Work, Employment and Society 4 (June):157-188.

Handel, Michael, and Maury Gittleman. 1999. "Is There a Wage Payoff to Innovative Work Practices?” Working Paper No. 288. Annandale-on-Hudson, NY: Jerome Levy Economics Institute.

Handy, Charles. 1991. The Age of Unreason. London: Business Books.

Harker, Patrick T., ed. 1995. The Service Productivity and Quality Challenge. Boston, MA: Kluwer Academic Publishers.

Helper, Susan, David I. Levine, and Elliot Bendoly. 2001. "Employee Involvement and Pay at U.S. and Canadian Auto Suppliers." Institute of Industrial Relations Working Paper No. 71. University of California, Berkeley.

Hom, Peter W., and Rodger W. Griffith. 1995. Employee Turnover. Cincinnati: South-Western. Horwitz, Frank 1995. "Flexible Work Practices in South Africa: Economic, Labour Relations, and Regulatory Considerations.” Industrial Relations Journal 26 (December):257-266.

Houseman, Susan N. 2001. "Why Employers Use Flexible Staffing Arrangements: Evidence from an Establishment Survey.” Industrial and Labor Relations Review 55 (October):149-170.

Houseman, Susan N., and Anne E. Polivka. 2000. “The Implications of Flexible Staffing

Arrangements for Job Stability." In On the Job: Is Long-Term Employment a Thing of the Past?, edited by

David Neumark, pp. 427-462. New York, NY: Russell Sage Foundation.

Hunter, John E., and Frank L. Schmidt. 1982. "Fitting People to Jobs: The Impact of Personnel

Selection on National Productivity." In Human Performance and Productivity: Vol. 1, Human Capability

Assessment, edited by Marvin Dunnette and Edwin Fleishman, pp. 232-284. Hillsdale, NJ: Erlbaum.

Hunter, Larry W. 2000. "The Adoption of Innovative Work Practices in Service Establishments."

International Journal of Human Resources 11 (June):477-496.

Hunter, Larry W., Annette Bernhardt, Katherine L. Hughes, and Eva Skuratowicz. 2001. "It's Not Just the ATMs: Technology, Firm Strategies, Jobs, and Earnings in Retail Banking.” Industrial and Labor 
Relations Review 54 (October):402-424.

Hunter, Larry, and Lorin Hitt. 2001. "What Makes for a High Performance Workplace? Evidence from Retail Bank Branches.” Working paper. Philadelphia, PA: Wharton School Department of

Management.

Hunter, Laurie, Alan McGregor, John MacInnes, and Alan Sproull. 1993. “The 'Flexible Firm': Strategy and Segmentation.” British Journal of Industrial Relations 31 (September):383-407.

Huselid, Mark A. 1995. “The Impact of Human Resource Management Practices on Turnover, Productivity and Corporate Financial Performance.” Academy of Management Journal 38 (June):635-672.

Ichniowski, Casey, Kathryn Shaw, and Giovanna Premushi. 1997. "The Effects of Human Resources Management Practices on Productivity: A Study of Steel Finishing Lines.” American Economic Review 87 (June):291-313.

Jacoby, Sanford. 1984. Employing Bureaucracy: Managers, Unions, and the Transformation of Work in American Industry. New York: Columbia University Press.

Kalleberg, Arne L. 1997. Nonstandard Work, Substandard Jobs: Flexible Work Arrangements in the U.S. Washington, D.C.: Economic Policy Institute.

Kalleberg, Arne L. 2001. “Organizing Flexibility: The Flexible Firm in a New Century.” British Journal of Industrial Relations 39 (December): 479-504.

Kalleberg, Arne L., and Jeremy Reynolds. 2000. “Organization Size and Flexible Staffing Arrangements in the United States." In Nonstandard Work: The Nature and Challenges of Changing Employment Arrangements, edited by Francoise Carre, Marianne A. Ferber, Lonnie Golden, and Stephen A. Herzenberg, pp. 145-165. Madison, WI: Industrial Relations Research Association.

Kaplan, Robert B., and Laura Murdock. 1991. “Core Process Redesign.” The McKinsey Quarterly 2 (Summer):27-43.

Katz, Harry C. 1985. Shifting Gears: Changing Labor Relations in the U.S. Automobile Industry. Cambridge, MA: MIT Press.

Kim, Marlene. 1999. "Where the Grass is Greener: Voluntary Turnover and Wage Premiums." 
Industrial Relations 38 (October):584-602.

Kochan, Thomas, and Paul Osterman. 1994. The Mutual Gains Enterprise: Forging a Winning

Partnership Among Labor, Management, and Government. Boston, MA: Harvard Business School Press.

Lawler, Edward E. 1982. “Increasing Worker Involvement to Enhance Organizational

Effectiveness." In Change in Organizations, edited by Paul Goodman, pp. 280-315. San Francisco, CA:

Jossey-Bass.

Levine, David. 1992. "What Do Wages Buy?” Administrative Science Quarterly 38

(September):462-483.

Levine, David I., and Richard J. Parkin. 1994. "Work Organization, Employment Security, and

Macroeconomic Stability.” Journal of Economic Behavior and Organization 24 (August):251-271.

Lorenz, Edward H. 1992. “Trust and the Flexible Firm: International Comparisons.” Industrial

Relations 31 (July):455-472.

McCall, Brian P. 1990. “Occupational Matching: A Test of Sorts.” Journal of Political Economy 98

(February):45-69.

McLaughlin, Kenneth J. 1991. “A Theory of Quits and Layoffs with Efficient Turnover.” Journal of

Political Economy 99 (February):1-29.

Medoff, James. 1979. "Layoffs and Alternatives Under Trade Unions in U.S. Manufacturing."

American Economic Review 69 (June):380-395.

Mobley, William H. 1982. Employee Turnover: Causes, Consequences, and Control. Reading, MA:

Addison-Wesley.

Mowday, Richard T., Lyman W. Porter, and William H. Mobley. 1982. Employee-Organizational

Linkages. New York, NY: Academic Press.

Neumark, David, ed. 2000. On the Job: Is Long-Term Employment a Thing of the Past? New York,

NY: Russell Sage Foundation.

Neumark, David, and Deborah Reed. 2001. "Employment Relationships in the New Economy."

Unpublished paper. Michigan State University. 
Osterman, Paul. 1987. “Turnover, Employment Security, and the Performance of the Firm.” In Human Resources and the Performance of the Firm, edited by Morris Kleiner, Richard Block, Myron Roomkin, and Sydney Salsburg, pp. 275-313. Madison, WI: Industrial Relations Research Association. Osterman, Paul. 2000. "Work Reorganization in an Era of Restructuring: Trends in Diffusion and Effects on Employee Welfare.” Industrial and Labor Relations Review 53 (January):179-196. Ouchi, William. 1981. Theory Z: How American Business Can Meet the Japanese Challenge. Reading, MA: Addison-Wesley.

Parker, Michael, and Jane Slaughter. 1988. Choosing Sides: Unions and the Team Concept. Boston, MA: South End Press.

Penn, Roger, Kari Lilja, and Hilda Scattergood. 1992. "Flexibility and Employment Patterns in the Contemporary Paper Industry: A Comparative Analysis of Mills in Britain and Finland.” Industrial Relations Journal 23 (Autumn):214-223.

Pinfield, Lawrence T., and James S. Atkinson. 1988. "Employment: The Flexible Firm.” Canadian Business Review 15 (Winter):17-19.

Piore, Michael, and Charles Sabel. 1984. The Second Industrial Divide. New York, NY: Basic Books. 
Polivka, Anne E., Sharon R. Cohany, and Steven Hipple. 2000. "Definition, Composition, and Economic Consequences of the Nonstandard Workforce.” In Nonstandard Work: The Nature and Challenges of Changing Employment Arrangements, edited by Francoise Carre, Marianne A. Ferber, Lonnie Golden, and Stephen A. Herzenberg, pp. 41-94. Madison, WI: Industrial Relations Research Association.

Powell, Irene, Mark Montgomery, and James Cosgrove. 1994. “Compensation Structure and Establishment Quit and Fire Rates.” Industrial Relations 33 (Spring):229-248.

Price, James L. 1977. The Study of Turnover. Ames, IA: The Iowa State University Press.

Rodgers, Ronald. 2000. "Commitment-Based Employment Relationships and High Performance Work Systems: A Theory-Driven Research Strategy to Bring the Traditional Concepts in Line with the Empirical Evidence." Working paper. Singapore: The National University of Singapore Faculty of Business Administration.

Salop, Steven C. 1979. “A Model of the Natural Rate of Unemployment.” American Economic Review 69 (March):117-125.

Shapiro, Carl, and Joseph E. Stiglitz. 1984. "Equilibrium Unemployment as a Worker Discipline Device.” American Economic Review 74 (June):433-444.

Sharna, Basu, and LanLuh L. Luh. 1994. "Labour Market Flexibilities as HRM Strategies: The Example of Singapore.” Journal of Asian Business 10 (March):61-77.

Smith, Vicky. 1997. "New Forms of Work Organization.” Annual Review of Sociology 23:315-325.

Topel, Robert. 1984. “On Layoffs and Unemployment Insurance.” American Economic Review 73

(September):541-559.

Thompson. 1967. Organizations in Action. New York: McGraw-Hill.

Wilson, Nicholas, John R. Cable, and Michael J. Peel. 1990. "Quit Rates and the Impact of Participation, ProfitSharing and Unionization: Empirical Evidence from U.K. Engineering Firms.” British Journal of Industrial Relations 28 (July):197-211. 
Table 1: Mean Turnover Rates and Proportions Using Contingent Workers, by Industry and Size Category ${ }^{\mathrm{a}}$

Full sample

Industry:

Food and tobacco

Textiles and apparel

Lumber and paper products

Printing and publishing

Chemical and petroleum

Primary metals

Fabricated metals

Machinery and instruments

Transportation equipment

Other and miscellaneous manufacturing

Construction

Transportation services

Communications

Utilities

Wholesale trade

Retail trade

Finance

Insurance and real estate

Hotels, rooming houses, camps, and other lodging places

Business services

Health services

Size:

20 to 49

50 to 99

100-249

250-999

$1000+$

Consistency checks:

Are any of your employees represented by a union? (Yes/No)

In the past three years, has the size of the establishment's workforce increased, stayed the same, or decreased?

Increased

Stayed the same

Decreased

$\begin{gathered}\text { Involuntary } \\ \text { turnover }\end{gathered}$

(1)

.066

.060

.089

.065

.090

.051

.083

.049

.032

.117

.076

.056

.054

.043

.022

.051

.084

.029

.052

.110

.059

.041

.064

.068

.067

.067

.060

$.062 / .066$

$.485 / .409$

$.124 / .205$

$480 / 1356$
$\underline{\mathrm{N}}$

$\begin{array}{lc}(3) & (4) \\ 197 & 1836\end{array}$

$.143 \quad 129$

$.215 \quad 86$

$.156 \quad 130$

$.097 \quad 101$

$.079 \quad 98$

$.137 \quad 130$

$.120 \quad 111$

$.103 \quad 133$

$.146 \quad 107$

$.141 \quad 136$

$.147 \quad 59$

$.207 \quad 29$

$.065 \quad 60$

$.115 \quad 93$

$.292 \quad 67$

$.125 \quad 38$

$.083 \quad 45$

$.392 \quad 69$

$.255 \quad 61$

$.141 \quad 72$

$.163 \quad 331$

$.251 \quad 320$

$\begin{array}{ll}.250 & 369\end{array}$

$\begin{array}{lll}.689 & .181 & 528 \\ .853 & .176 & 288\end{array}$

$\begin{array}{lll}.689 & .181 & 528 \\ .853 & .176 & 288\end{array}$
$.106 \quad 82$

29
6
30
101
8
30
11
33
107
36
8
9
9
6
3
7
38
5

331
320
369
528
288

$\begin{array}{ccc}\begin{array}{c}\text { Voluntary } \\ \text { contingent workers } \\ \text { turnover }\end{array} & \frac{\mathrm{N}}{(3)} & \frac{(4)}{4)} \\ .417 & .197 & 1836\end{array}$


Table 2: Descriptive Statistics for Internally Flexible Work Practices ${ }^{\mathrm{a}}$

\section{Overall Non-manufacturing Manufacturing}

(1)

(2)

(3)

Employer practices related to internal flexibility:

Proportion of non-managerial and

non-supervisory workers

involved in:

Regularly scheduled meetings to discuss

work-related problems?

.58

.61

.50

Self-managed teams?

.18

.18

.17

Job rotation?

.20

.19

.26

Does establishment contribute toward

stock options or profit sharing? (Yes/No)

.39

.37

.45

$\mathrm{N}$

1836

675

1161

_ Estimates are sample weighted to be representative of establishments. 
Table 3: Mean Turnover Rates and Proportions Using Contingent Workers, by Employer Practices Related to Internal Flexibility ${ }^{\mathrm{a}}$

Employer practices related to internal flexibility:

Proportion using any
contingent workers

Non-managerial and non-supervisory workers

involved in:

Regularly scheduled meetings to discuss

work-related problems? (Yes/No)

Self-managed teams? (Yes/No)

Job rotation? (Yes/No)

Does establishment contribute toward

stock options or profit sharing? (Yes/No)

Key controls:

Has establishment undergone re-engineering

within the past three years? (Yes/No)

Has establishment participated in any benchmarking programs that compare practices and performance with other organizations? (Yes/No)

Have skills required to perform the typical worker's job at an acceptable level increased, stayed the same, or decreased in the past three years?
Increased
Stayed the same

Decreased
(1)

$.055^{* *}$

.079

.054

(2)

$\begin{array}{llll}.069 / .054^{* *} & .447 / .311^{* *} & .214 / .135^{* *} & 1580 / 256 \\ .071 / .062 & .434 / .406 & .214 / .186^{*} & 798 / 1038 \\ .068 / .063 & .413 / .421 & .252 / .139^{* *} & 1042 / 794 \\ .071 / .062^{*} & .531 / .345^{* *} & .226 / .178^{* *} & 962 / 874\end{array}$

$.068 / .065$

$.580 / .371^{* *}$

$.167 / .205^{* *}$

$623 / 1213$

$724 / 1112$

$\underline{(4)}$

$.218 / .188^{*}$

623/1213

1056

731

.201

.221

49

- ${ }^{a}$ Estimates are sample weighted to be representative of establishments. In columns (1), (2), and (3), estimated differences significant at the one-percent (five-percent) level are indicated with ** (*); for the skill change question, these are reported for differences relative to the "stayed the same" category. 
Table 6: Regression Estimates for Voluntary Turnover ${ }^{\mathrm{a}}$

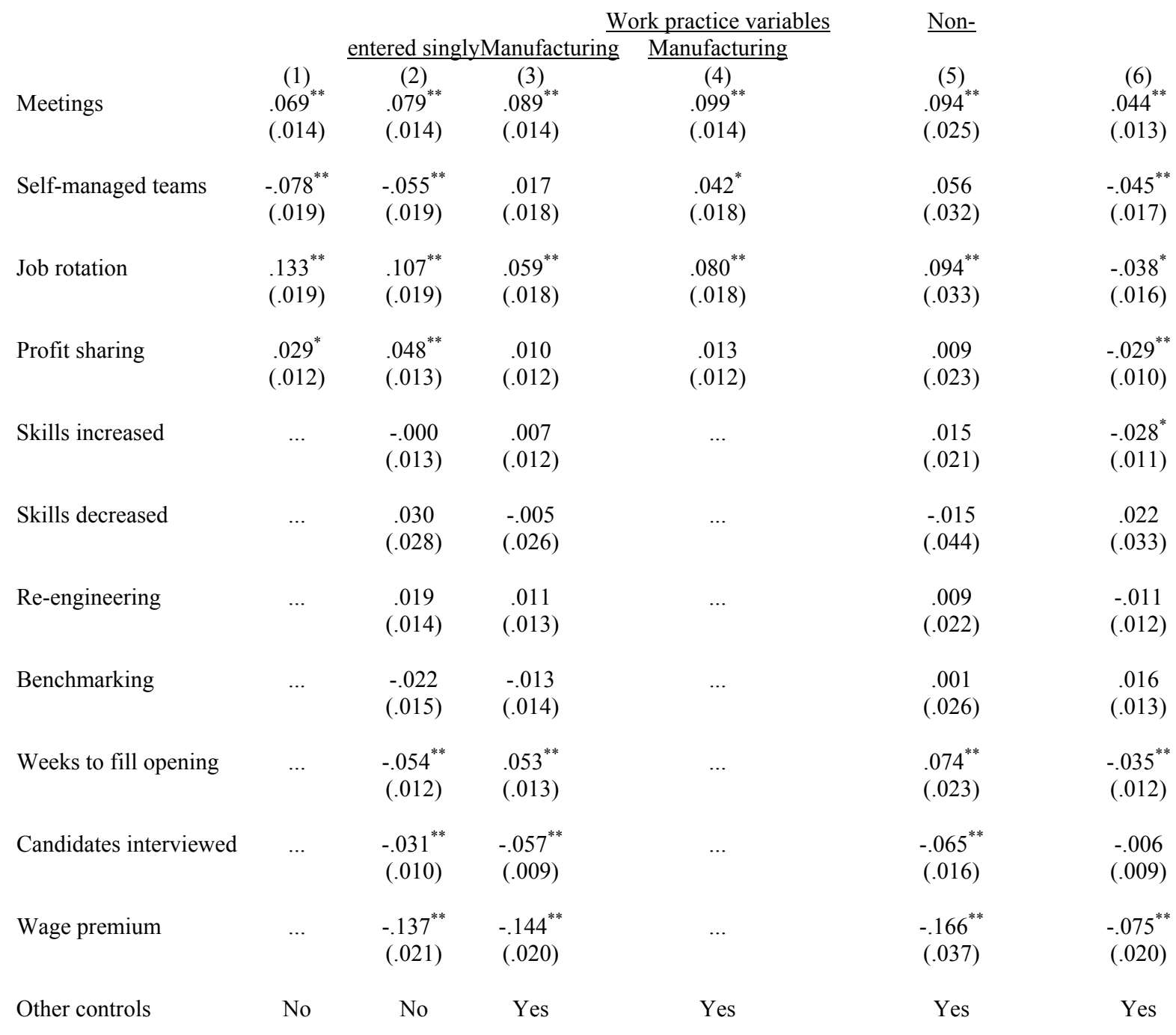

\footnotetext{
${ }_{-}^{\mathrm{a}}$ The dependent variable is the voluntary turnover rate. Estimates are for one-tailed Tobits. See notes to Table 4 for list of control variables and other details.
} 
Table 4: Regression Estimates for Involuntary Turnover ${ }^{\mathrm{a}}$

\begin{tabular}{|c|c|c|c|c|c|c|}
\hline Meetings & $\begin{array}{c}(1) \\
.001 \\
(.006)\end{array}$ & $\begin{array}{c}(2) \\
.004 \\
(.007)\end{array}$ & $\begin{array}{c}(3) \\
.010 \\
(.007)\end{array}$ & $\begin{array}{c}\frac{\text { Work practice variables }}{\text { entered singly }} \\
(4) \\
.009 \\
(.007)\end{array}$ & $\begin{array}{c}\frac{\text { Non- }}{\text { Manufacturing }} \\
(5) \\
.007 \\
(.011)\end{array}$ & $\begin{array}{c}\text { Manufacturing } \\
(6) \\
.018 \\
(.010)\end{array}$ \\
\hline Self-managed teams & $\begin{array}{l}-.017 \\
(.009)\end{array}$ & $\begin{array}{c}-.014 \\
(.009)\end{array}$ & $\begin{array}{l}-.015 \\
(.009)\end{array}$ & $\begin{array}{l}-.012 \\
(.009)\end{array}$ & $\begin{array}{l}.003 \\
(.015)\end{array}$ & $\begin{array}{l}-.050^{* *} \\
(.013)\end{array}$ \\
\hline Job rotation & $\begin{array}{l}.029^{* *} \\
(.008)\end{array}$ & $\begin{array}{l}.022^{* *} \\
(.008)\end{array}$ & $\begin{array}{c}.008 \\
(.009)\end{array}$ & $\begin{array}{l}.010 \\
(.009)\end{array}$ & $\begin{array}{l}-.002 \\
(.015)\end{array}$ & $\begin{array}{l}-.000 \\
(.012)\end{array}$ \\
\hline Profit sharing & $\begin{array}{c}.006 \\
(.006)\end{array}$ & $\begin{array}{c}.008 \\
(.006)\end{array}$ & $\begin{array}{c}.011 \\
(.006)\end{array}$ & $\begin{array}{l}.011 \\
(.006)\end{array}$ & $\begin{array}{l}.026^{*} \\
(.010)\end{array}$ & $\begin{array}{l}-.018^{*} \\
(.008)\end{array}$ \\
\hline Skills increased & $\ldots$ & $\begin{array}{l}-.029^{* *} \\
(.006)\end{array}$ & $\begin{array}{l}-.027^{* *} \\
(.006)\end{array}$ & $\ldots$ & $\begin{array}{c}-.041^{* *} \\
(.010)\end{array}$ & $\begin{array}{l}-.008 \\
(.009)\end{array}$ \\
\hline Skills decreased & $\ldots$ & $\begin{array}{l}-.025 \\
(.013)\end{array}$ & $\begin{array}{l}-.013 \\
(.013)\end{array}$ & $\ldots$ & $\begin{array}{l}-.006 \\
(.020)\end{array}$ & $\begin{array}{l}-.003 \\
(.026)\end{array}$ \\
\hline Re-engineering & $\ldots$ & $\begin{array}{l}.024^{* *} \\
(.006)\end{array}$ & $\begin{array}{l}.025^{* *} \\
(.006)\end{array}$ & $\ldots$ & $\begin{array}{l}.024^{*} \\
(.010)\end{array}$ & $\begin{array}{l}.027^{* *} \\
(.009)\end{array}$ \\
\hline Benchmarking & $\ldots$ & $\begin{array}{c}.011 \\
(.007)\end{array}$ & $\begin{array}{c}.006 \\
(.007)\end{array}$ & $\ldots$ & $\begin{array}{c}.013 \\
(.012)\end{array}$ & $\begin{array}{l}-.015 \\
(.010)\end{array}$ \\
\hline Weeks to fill opening & $\ldots$ & $\begin{array}{l}-.019^{* *} \\
(.006)\end{array}$ & $\begin{array}{c}.000 \\
(.007)\end{array}$ & $\ldots$ & $\begin{array}{l}-.000 \\
(.011)\end{array}$ & $\begin{array}{c}.001 \\
(.009)\end{array}$ \\
\hline Candidates interviewed & $\ldots$ & $\begin{array}{c}.002 \\
(.004)\end{array}$ & $\begin{array}{l}-.008 \\
(.004)\end{array}$ & $\ldots$ & $\begin{array}{l}-.006 \\
(.007)\end{array}$ & $\begin{array}{c}.002 \\
(.007)\end{array}$ \\
\hline Wage premium & $\ldots$ & $\begin{array}{c}-.006 \\
(.010)\end{array}$ & $\begin{array}{l}-.016 \\
(.010)\end{array}$ & $\ldots$ & $\begin{array}{l}-.021 \\
(.016)\end{array}$ & $\begin{array}{l}-.026 \\
(.015)\end{array}$ \\
\hline Other controls & No & No & Yes & Yes & Yes & Yes \\
\hline
\end{tabular}

\footnotetext{
${ }_{-}^{\mathrm{a}}$ The dependent variable is the involuntary turnover rate. Estimates are for one-tailed Tobits. There are 1836 observations in columns (1)-(4), 675 in column (5), and 1161 in column (6). Estimates are sample weighted to be representative of establishments. For the work practice variables, the variables for meetings, self-managed teams, and job rotation are the proportions of workers involved, in contrast to Table 3 . "Other controls" include: industry (21 two-digit industries); the percentage of non-managerial/non-supervisory workers unionized; the percent female and the percent minority; size ( 5 categories based on employment); employment change ( 3 categories for whether the workforce increased, stayed the same, or decreased in the past three years); establishments in multi-unit firms; benefits (severance, pension, medical insurance, dental insurance, child care, family leave, life insurance, sick pay, vacation); occupation (percent managers/professionals, percent supervisors, percent technical/technical support, percent office/clerical/sales/customer service, and percent production); education (average education for managers and supervisors, and for other occupations, and an interaction of the latter with the percentage of workers in these occupations); months for typical new worker to become proficient; and age of equipment and machinery, as a proxy for plant age (percent of machinery and equipment less than 1 year old, 1-4 years old, 510 years old, and more than 10 years old). The wage premium is the residual from a regression of log average salary of permanent workers on the education, occupation, industry, minority and female representation, and size variables, as well as the share of hours that are overtime. The wage premium regression is always estimated using sample weights, to be representative of establishments. Column (4) reports results for four separate specifications; the control variables in each are the same as in column $(3) . *^{*}(*)$ indicates that the estimate was statistically significantly different from zero at the one-percent (five-percent) level.
} 
Table 5: Probit Estimates for Use of Contingent Workers ${ }^{\mathrm{a}}$

\begin{tabular}{|c|c|c|c|c|c|c|}
\hline Meetings & $\begin{array}{l}(1) \\
.026 \\
(.028)\end{array}$ & $\begin{array}{c}(2) \\
-.015 \\
(.029)\end{array}$ & $\begin{array}{c}(3) \\
-.011 \\
(.034)\end{array}$ & $\begin{array}{c}\frac{\text { Work practice variables }}{\text { entered singly }} \\
(4) \\
-.013 \\
(.033)\end{array}$ & $\begin{array}{c}\frac{\text { Non- }}{\text { Manufacturing }} \\
(5) \\
-.002 \\
(.057)\end{array}$ & $\begin{array}{c}\text { Manufacturing } \\
(6) \\
.027 \\
(.043)\end{array}$ \\
\hline Self-managed teams & $\begin{array}{l}-.064 \\
(.038)\end{array}$ & $\begin{array}{c}-.121^{* *} \\
(.040)\end{array}$ & $\begin{array}{l}-.049 \\
(.045)\end{array}$ & $\begin{array}{l}-.053 \\
(.044)\end{array}$ & $\begin{array}{l}-.104 \\
(.076)\end{array}$ & $\begin{array}{l}.136^{*} \\
(.060)\end{array}$ \\
\hline Job rotation & $\begin{array}{l}-.020 \\
(.036)\end{array}$ & $\begin{array}{l}-.012 \\
(.038)\end{array}$ & $\begin{array}{l}-.010 \\
(.043)\end{array}$ & $\begin{array}{l}-.009 \\
(.043)\end{array}$ & $\begin{array}{c}.012 \\
(.074)\end{array}$ & $\begin{array}{l}-.077 \\
(.054)\end{array}$ \\
\hline Profit sharing & $\begin{array}{l}.183^{* *} \\
(.024)\end{array}$ & $\begin{array}{l}.113^{* *} \\
(.025)\end{array}$ & $\begin{array}{l}.091^{* *} \\
(.030)\end{array}$ & $\begin{array}{l}.090^{* *} \\
(.030)\end{array}$ & $\begin{array}{l}.117^{*} \\
(.053)\end{array}$ & $\begin{array}{l}-.017 \\
(.035)\end{array}$ \\
\hline Skills increased & $\ldots$ & $\begin{array}{l}.090^{* *} \\
(.026)\end{array}$ & $\begin{array}{l}.085^{* *} \\
(.029)\end{array}$ & $\ldots$ & $\begin{array}{c}.091 \\
(.048)\end{array}$ & $\begin{array}{l}.043 \\
(.038)\end{array}$ \\
\hline Skills decreased & $\ldots$ & $\begin{array}{l}-.204^{* *} \\
(.048)\end{array}$ & $\begin{array}{l}-.072 \\
(.067)\end{array}$ & $\ldots$ & $\begin{array}{l}-.073 \\
(.101)\end{array}$ & $\begin{array}{l}-.027 \\
(.114)\end{array}$ \\
\hline Re-engineering & $\ldots$ & $\begin{array}{l}.107^{* *} \\
(.028)\end{array}$ & $\begin{array}{l}.075^{*} \\
(.031)\end{array}$ & $\ldots$ & $\begin{array}{l}.107^{*} \\
(.052)\end{array}$ & $\begin{array}{l}-.045^{*} \\
(.042)\end{array}$ \\
\hline Benchmarking & $\cdots$ & $\begin{array}{l}.154^{* *} \\
(.031)\end{array}$ & $\begin{array}{l}.096^{* *} \\
(.036)\end{array}$ & $\cdots$ & $\begin{array}{l}.123^{*} \\
(.062)\end{array}$ & $\begin{array}{c}.053 \\
(.043)\end{array}$ \\
\hline Weeks to fill opening & $\ldots$ & $\begin{array}{l}.210^{* *} \\
(.025)\end{array}$ & $\begin{array}{l}.106^{* *} \\
(.031)\end{array}$ & $\cdots$ & $\begin{array}{l}.120^{*} \\
(.050)\end{array}$ & $\begin{array}{c}.072 \\
(.043)\end{array}$ \\
\hline Candidates interviewed & $\ldots$ & $\begin{array}{c}-.080^{* *} \\
(.020)\end{array}$ & $\begin{array}{l}-.048^{*} \\
(.022)\end{array}$ & $\cdots$ & $\begin{array}{l}-.049 \\
(.036)\end{array}$ & $\begin{array}{l}-.020 \\
(.031)\end{array}$ \\
\hline Wage premium & $\cdots$ & $\begin{array}{c}-.185^{* *} \\
(.043)\end{array}$ & $\begin{array}{l}-.127^{*} \\
(.051)\end{array}$ & $\ldots$ & $\begin{array}{l}-.113 \\
(.085)\end{array}$ & $\begin{array}{l}-.155^{*} \\
(.069)\end{array}$ \\
\hline Other controls & No & No & Yes & Yes & Yes & Yes \\
\hline
\end{tabular}

${ }_{-}^{\text {a }}$ The dependent variable is a dummy variable for whether contingent workers are used. Estimates are for probits, with derivatives of probability of outcome reported, and standard errors adjusted to replicate t-statistics of probit coefficient estimates. See notes to Table 4 for list of control variables and other details. 


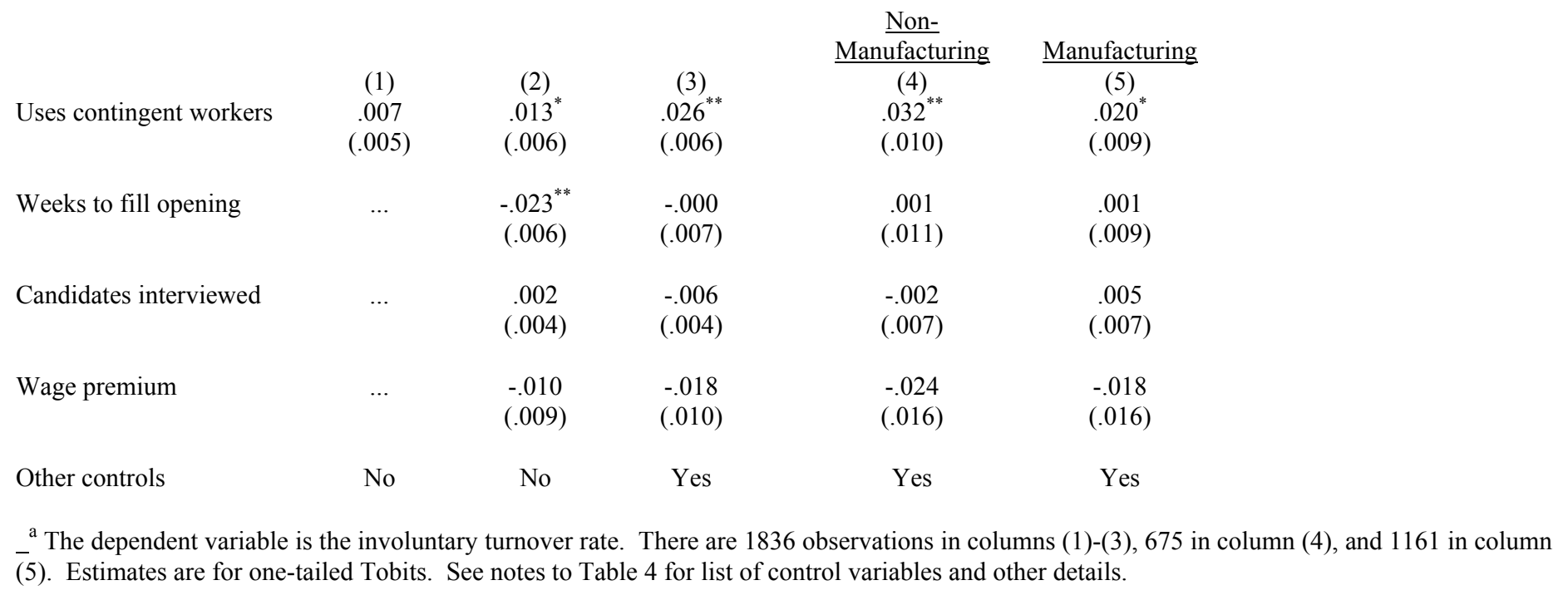

Overall sample sizes:

Full sample

After dropping observations with missing dependent variables

After dropping observations with missing data on work practices

After dropping observations with missing data on skill changes, recruitment, or wages and hours

After dropping observations with missing data on occupation, education, percent female/minority, or benefits

After dropping observations with missing data on capital stock, multi-unit firms, unionization, training, or employment changes

Distribution of establishments (weighted for overall non-response):

By industry:

Food and tobacco

Textile and apparel

Lumber and paper products

Printing and publishing

Chemical and petroleum

Primary metals

Fabricated metals

Machinery and instruments

Transportation equipment

Other and miscellaneous manufacturing

Construction

Transportation services

\section{Full sample}

1.35

1.58

1.72

1.87

.85

.56

2.08

4.02

.64

3.17

7.44

3.02

\section{$\underline{\text { Analysis sample }}$}

1.54

1.90

2.38

2.23

.96

.71

2.28

4.99

.76

3.90

6.31

3.03 


$\begin{array}{lcc}\text { Communications } & 1.67 & 1.74 \\ \text { Utilities } & .98 & .98 \\ \text { Wholesale trade } & 10.59 & 12.58 \\ \text { Retail trade } & 34.87 & 34.87 \\ \text { Finance } & 4.12 & 3.50 \\ \text { Insurance and real estate } & 2.16 & 1.83 \\ \text { Hotels, rooming houses, camps, } & & \\ \text { and other lodging places } & 1.87 & 2.08 \\ \text { Business services } & 7.67 & 5.64 \\ \text { Health services } & 7.78 & 5.80 \\ & & \\ \text { By size: } & & .60 \\ <50 & .60 & .24 \\ \text { 50-99 } & .22 & .13 \\ \text { 100-249 } & .13 & .04 \\ \text { 250-999 } & .04 & .01 \\ \text { 31000 } & .01 & \\ \text { By unionization: } & & .10 \\ \text { Unionized } & .10 & \\ \end{array}$




\section{$\underline{\text { Endnotes }}$}

1. While some research has focused on the potential positive aspects of turnover (Dalton, et al. 1981), it is fair to say that most of the research has considered turnover as a problem to be addressed, both for employees and for employers, and has concentrated on how it might be reduced.

2. Note that by "churning" here we refer generally to strategies and behaviors that generate instability in the attachment of workers to firms-i.e., involuntary turnover, contingent work, or voluntary turnover-rather than a narrower definition focusing solely on volatility in a firm's or establishment's employment.

3. This could be driven by variation in the environment facing firms that shifts the costs or benefits of both types of flexibility.

4. One exception is Kalleberg and Reynolds (2000), who explore the role of organizational size in the use of flexible staffing arrangements. They describe (although they report few results) some specifications controlling for organizational strategy and human resource practices, although not functionally flexible practices per se.

5. The arguments regarding the high performance work model and functional flexibility are not identical, however. As Huselid (1995) observes, the hypotheses from the high performance literature are typically directed at voluntary turnover and operate through the perceptions of individuals. The hypotheses from functionally flexible firms, in contrast, are directed at involuntary turnover and operate through organizational-level practices. Nonetheless, the literature 
on high performance work practices does posit some relationships with involuntary turnover. The argument is that job security is a necessary condition for the successful introduction of high performance work systems because employees do not want to suggest improvements that could cause their own jobs to be cut; similarly, at a psychological level reciprocity causes them to respond to the employer's promise of security with their own promises of involvement (Kochan and Osterman 1994; Helper, et al., 2001).

6. We refer to the likelihood of using (or not using) contingent work because our empirical work has to rely on an incidence measure for this type of work arrangement, rather than a percentage of work supplied by contingent labor.

7. For a review of literature on this topic, see Levine and Parkin (1994) •

8. In addition, the distinction between voluntary and involuntary turnover is not always meaningful. In economic models of efficient turnover (described in McLaughlin 1991) the conceptual distinction is meaningless, and empirically it may be difficult to distinguish ex post whether a termination was voluntary or not. As Carmichael (1983) explains, under some circumstances (such as when there is a severance payment), "A worker wanting to quit, for example, may simply behave badly enough (i.e., reduce his productivity enough) to induce a fire'" (p. 251).

9. Less than ten percent of the U.K. workforce is with employers who report that they had a conscious core-periphery labor strategy (Hunter, et al. 1993). 
10. There was an earlier wave (NES I) conducted in 1994. However, only in the NES II were establishments asked to report their rates of voluntary and involuntary turnover and their use of contingent workers, so our analysis is restricted to the second survey. The only related measure available on both surveys is the percentage of workers with less than one year of tenure. The tenure question is not quite as useful, because it can be strongly influenced by establishment growth irrespective of turnover, although in principle we could control for growth using information on changes in employment. However, the more significant problem is that this question differs across the surveys, asking about currently employed workers in the NES I, and current permanent workers in the NES II. Thus, changes in this tenure variable could reflect a number of things not necessarily related to turnover.

11. The NES II oversampled establishments in manufacturing and establishments with more than 100 employees. It also oversampled establishments in states involved in particular educational reform efforts (2,000 completed interviews in California, Kentucky, Michigan, Maryland, and Pennsylvania). The sample made available to us drops the state oversamples, resulting in a data set of approximately 3,100 completed establishment interviews.

12. Additional details on the NES data are provided in Cappelli and Neumark (2001).

13. The interviewer was instructed to define these workers, if necessary, as those "for whom your establishment did not withhold payroll taxes," so this definition should include contract workers 
narrowly-defined as well as independent contractors.

The survey also included a follow-up question regarding the number of such workers. However, given the short-term nature of this type of employment, absent any information on the duration of employment of such workers there is no way to convert the latter into a percentage of work supplied by contingent labor. In addition, Census confidentiality requirements limited us to working with a data set measuring establishment size with five categorical variables, rather than the actual employment level, so constructing a percentage of work supplied by contingent labor would not have been possible regardless. Consequently, we restrict attention to the incidence question.

The NES also has information on part-time workers. Part-time employment is sometimes included in definitions of nonstandard work and contingent work. But part-time work may well be steady and predictable, especially voluntary part-time work, and we have no information on voluntary vs. involuntary part time. We therefore do not study part-time employment.

14. "Contingent work"' is a label we have chosen to apply, although arguably the contingent workforce consists of more than just these categories of workers. In the CPS, "contingent work"' is measured as work that is temporary and in which the employee cannot remain as long as he or she wishes. This will generally cover agency workers and contractors, but not necessarily leased workers. In recent CPS contingent worker surveys, contractors and temporary help employees constitute about two-thirds of the "contingent or alternative" work force (Neumark and Reed, 2001). 
15. While this variable is somewhat vague, workplace meetings in which workers address problems such as production technology, work organization, safety, and other issues are typically included in descriptions of new organizations of work incorporating employee involvement and teamwork (e.g., Cappelli, et al. 1997). While information about the content of these meetings is unavailable, it seems likely that higher percentages of workers involved are associated with more reliance on employee involvement, etc.

16. Other research has found a negative relationship between profitsharing practices per se and voluntary turnover (Wilson, et al. 1990).

17. Shapiro and Stiglitz (1984) provide the theoretical basis for this argument, and Cappelli and Chauvin (1991) present supporting empirical evidence.

18. Whether establishment characteristics should be included depends on whether one believes that wage differences associated with these characteristics reflect differences in worker skills or wage premiums (for evidence, see Blackburn and Neumark (1992) and Brown and Medoff (1989)). All of the specifications reported in the paper were also estimated using a wage premium constructed from a regression dropping the size and industry controls, with little effect on the results.

19. Some observers believe that the kind of work systems that make use of teamwork and employee involvement also typically include other practices such as more intensive selection and higher wages; to some extent higher wages may, like profit sharing, reinforce involvement by rewarding workers (e.g., Appelbaum and Batt 1994).

20. Additional details regarding these controls are given in the 
notes to Table 4 .

21. No doubt there are many possible measures of industry and establishment volatility, but we believe all of the volatility relevant here would play itself out through changes in employment levels. There is also an issue as to whether size itself is an endogenous factor. Other things equal, establishments may be smaller because of turnover. However, our size measures refer to the end of 1996 and our turnover measure covers calendar year 1997. Along with controlling for changes in size, this timing should mitigate some of the concern regarding endogeneity. Further, as noted above we use broad size categories, making it unlikely that much of the variation stems from changes in turnover.

22. Five percent of the observations reported voluntary turnover rates of zero, and 18 percent of the observations reported involuntary turnover rates of zero. However, results were similar using OLS.

23. Based on a 1995 Upjohn Institute survey of employers, Houseman (2001) reports that in the previous five years 78 percent of establishments used at least one of the following types of employment: temporary help agency workers; short-term hires; on-call workers; or contract workers. The 41.7 percent figure from the NES II is lower. The NES II survey refers to "contract, leased, or temporary agency workers,"' which likely excludes short-term hires and perhaps also oncall workers. In addition, the Upjohn survey has a window of five years rather than one, which might lead to a higher estimate. But the Upjohn survey also allows a computation of the percentage of establishments using agency temporaries in the past year, and this 
percentage alone (i.e., excluding contract or leased workers) slightly exceeds the estimated incidence of contingent work in the NES II. Thus, the difference in estimates is not easily explained. A referee has suggested that contingent work may be under-reported in the NES II because the questions on contingent work are embedded in the survey, and do not figure prominently as the survey's central feature.

24. In this panel of the table we highlight the descriptive statistics pertinent to the consistency checks.

25. The incidence estimates can also be contrasted with other data sources. Based on the BLS's 1995 Survey of Employer-Provided Training, Handel and Gittleman (1999) report a lower incidence of the use of job rotation and self-managed teams (with the discrepancy particularly large for the former-34 percent vs. 57 percent). These are both random samples of establishments, and the questions are not very dissimilar, so there is no obvious explanation for the differences. This should raise a caution flag to researchers that pinning down the exact incidence of various workplace practices is not necessarily a simple matter.

26. All variable measuring rates or percentages are defined as proportions ranging from zero to one, so, for example, the coefficient of .069 for the meetings variable implies that a ten-percent increase in workers involved in meetings (a .1 increase in the proportion) increases the voluntary turnover rate by .0069.

27. The correlation matrix is as follows:

Self-managed teams Job rotation Profi Meetings 
Job rotation

28. To avoid drawing inferences from the business services industry, which often supplies contingent workers to other employers, we re-ran all of our specifications involving contingent work excluding this industry. The results, which are available from the authors upon request, were unchanged.

29. Note that the findings regarding these variables were similar for contingent work, as reported in Table 5 .

30. With regard to the standard turnover hypotheses, the estimated coefficient of the wage premium is consistent across the two sectors, but not the estimated coefficients of the other selection proxies.

31. This latter scenario is the one that would be most accurately characterized as "complementarity"' in the economist's sense of the word. 